\title{
Prevalence of hypertension and associated risk factors in older adults in Kurdistan, Iraq
}

Mariwan Saka, ${ }^{1}$ Sherzad Shabu ${ }^{2}$ and Nazar Shabila²

${ }^{1}$ Department of Internal Medicine, College of Medicine, Hawler Medical University, Erbil, Kurdistan, Iraq. ${ }^{2}$ Department of Community Medicine, Hawler Medical University, Erbil, Kurdistan, Iraq. (Correspondence to: N. Shabila: nazarshabila@gmail.com).

\begin{abstract}
Background: Hypertension is an important public health problem and one of the leading risk factors for morbidity and mortality from cardiovascular diseases.

Aims: To determine the prevalence of hypertension in a population of older adults in Erbil, Kurdistan, Iraq and identify the risk factors associated with hypertension.

Methods: A community-based cross-sectional survey based on household visits was carried out from April to June 2017. The study involved 1480 adults selected through a multistage sampling method. We used a specially designed questionnaire to collect sociodemographic and clinical data from the participants through direct interview and measurement of blood pressure.

Results: Of the 1480 study participants, 809 (54.7\%) had hypertension. Of these 809 hypertensive patients, 375 (46.4\%) were known cases of hypertension and $434(53.6 \%)$ were diagnosed during the survey. The multivariate analysis identified age [odds ratio $(\mathrm{OR})=1.1,95 \%$ confidence interval $(\mathrm{CI})=1.08-1.11$ ], male sex $(\mathrm{OR}=2.72,95 \% \mathrm{CI}=1.91-3.87)$, unemployment $(\mathrm{OR}=$ $1.85,95 \% \mathrm{CI}=1.33-2.56)$, and obesity $(\mathrm{OR}=2.20,95 \% \mathrm{CI}=1.51-3.21)$ as significant factors associated with hypertension.
\end{abstract}

Conclusion: The prevalence of hypertension in Erbil City is high, with a high prevalence of undiagnosed hypertension. Treatment compliance was high but access to drugs was primarily from private pharmacies. This high prevalence of hypertension in Erbil City necessitates effective preventive and control measures, including comprehensive health education and screening programmes.

Keywords: elderly, household survey, hypertension, prevalence, risk factors

Citation: Saka M; Shabu S; Shabila N. Prevalence of hypertension and associated risk factors in a population sample of older adults in Kurdistan, Iraq. East Mediterr Health J. 2020;26(3):265-272. https://doi.org/10.26719/emhj.19.029

Received: 04/02/18; accepted: 03/06/18

Copyright (c) World Health Organization (WHO) 2020. Open Access. Some rights reserved. This work is available under the CC BY-NC-SA 3.o IGO license (https://creativecommons.org/licenses/by-nc-sa/3.o/igo).

\section{Introduction}

Hypertension is the most common cause of primary care visits, and it is an independent and a reversible risk factor for cardiovascular diseases (CVDs) such as myocardial infarction, stroke and renal failure. It can even lead to death if not diagnosed early and treated appropriately (1). Hypertension is considered to be a major public health problem worldwide (2). It is believed to be one of the leading causes of death and a frequent cause of outpatient visits (3). Regarding its contribution to the growing global pandemic of CVD, recently confirmed by the update of the Global Burden of Disease Study (2000), hypertension is estimated to be responsible for around 50\% of CVDs worldwide (4). It is also considered to be one of the main risk factors for cardiovascular mortality, accounting for $20-50 \%$ of all deaths (5).

Hypertension among the adult population is increasing, and its complications account for 9.4 million annual deaths worldwide. Low-income countries have the highest prevalence of hypertension. The prevalence of hypertension is highest in the African Region at $46 \%$ of adults aged $\geq 25$ years, and this proportion is increasing (6). About three-quarters of people with hypertension are from low- and middle-income countries, as access to healthcare, as well as awareness of the disease, are inadequate. In general, Middle Eastern countries have a high prevalence of hypertension. A study conducted in the Islamic Republic of Iran revealed that $>57 \%$ of people aged $\geq 60$ years have hypertension, compared to $3.6 \%$ of people aged < 30 years (7). Moreover, it is reported that, in 2001, the number of deaths resulting from hypertensive cardiac diseases in the Middle East and North Africa was 115 per 100000 , and the number of disability-adjusted life years resulting from hypertensive cardiac diseases was 1389 per $100000(8)$.

In 2006, a survey conducted in Iraq on chronic noncommunicable disease risk factors revealed that the prevalence of hypertension was $40.4 \%$ (9). The World Health Organization (WHO) Eastern Mediterranean Region health statistics published in 2008 revealed that the prevalence of hypertension in Iraq for both sexes was $29.4 \%(20.4-38.9 \%)(10)$. A household survey conducted in Thi-Qar Governorate in 2014 revealed that the overall prevalence of hypertension was $26.5 \%$ (11).

In low- and middle-income countries, many people with hypertension are not aware of their disease and the necessity for regular blood pressure checks. They may also not have access to drugs to control their hypertension 
and reduce mortality and morbidity from complications such as heart disease and stroke. People may simply be unaware of the health consequences or indifferent to the risks of untreated hypertension (12). Therefore, this study aimed to determine the prevalence of hypertension in a sample of older adults in Erbil City, Kurdistan, Iraq and identify the risk factors associated with hypertension.

\section{Methods}

This community-based cross-sectional survey based on household visits was conducted in Erbil City, Kurdistan, Iraq from April to June 2017. A multistage sampling method was used to collect the study subjects. In the first stage, Erbil was divided into 20 quarters based on the administrative map of the city, and a systematic random sampling method was used to select 30 households in each quarter. For each quarter, we determined a sampling interval $\mathrm{k}$ as the ratio of the estimated quarter size to the sample size of 30 . The first household in each quarter was selected randomly, and the next households were selected by selecting every kth household.

The study population included all the adult inhabitants of these households aged $\geq 18$ years. Data were collected through direct interview using a special questionnaire designed for this purpose. The questionnaire included personal and sociodemographic information such as age, sex, marital status, educational level, employment status and type of occupation. It also included questions on smoking, alcohol consumption, diet, salt intake and physical exercise. Systolic blood pressure (SBP) and diastolic blood pressure (DBP) were measured for each subject on 2 occasions: after $\geq 5$ minutes' rest, and then 5 minutes after the first reading. Subjects' weight and height were measured and body mass index was calculated. The surveyors were trained to administer the questionnaire and measure BP. A pilot study was conducted to test the validity and applicability of the questionnaire, and modifications were made accordingly. The pilot study revealed that the internal consistency (Cronbach's $\alpha$ ) estimation of the questionnaire was 0.79 and the reliability coefficient was 0.82 .

We used Epi-info to calculate the sample size, assuming that the prevalence of hypertension in Erbil City was similar to the previously reported $40 \%$ for Iraqi adults (13). We found that a sample size of 1473 was sufficient to achieve a $95 \%$ confidence interval (CI) for a prevalence $( \pm 2.5 \%)$ in this population. The sample size was increased to 1500 to accommodate for nonresponse. We assumed that each household would have 2 or 3 adults aged $\geq 18$ years and visiting 600 households would produce a sample of around 1500 participants. Therefore, we selected 30 households in each of the 20 quarters.

Ethical approval was obtained from the Research Ethics Committee at our institution. Approval was also obtained from Erbil Governor and Erbil Mayor Offices. Informed consent was obtained from the participants who were assured about the anonymity of the study. The participants were informed about their BP status, and those with elevated BP, especially patients with newly diagnosed hypertension, were advised to seek appropriate health care.

SPSS version 19 was used for data entry and analysis. The second BP measurement was used to determine hypertension. We used the 2017 American College of Cardiology/American Heart Association new guidelines for the prevention, detection, evaluation and management of high $\mathrm{BP}$ in adults that set a cutoff of 130/80 mmHg for hypertension (14). People with SBP $\geq$ $130 \mathrm{mmHg}$ and/or DBP $\geq 80 \mathrm{mmHg}$ during the second reading were considered to have hypertension. Student's $\mathrm{t}$ test was used to compare 2 independent sample means. The $\chi^{2}$ test was used for comparing proportions. $P<0.05$ was considered statistically significant. Multivariate analysis was based on binary logistic regression to adjust for and examine the independent effects of possible covariates. Odds ratios (ORs) and 95\% CIs were calculated. ORs were estimated to measure the strength of the associations while 95\% CIs and P values were estimated for significance testing.

\section{Results}

The survey identified 1480 adult participants in the 600 visited households. The mean (standard deviation) age of the participants was 46.4 (16.3) years with no significant difference between the mean age of men [46.7 (16.6) years] and women [46.2 (16.2) years] $(P=0.612)$. A total of $375(25.3 \%)$ participants were in the age group $\geq 60$ years, while $336(22.7 \%)$ were in the $30-39$ years age group and $307(20.7 \%)$ in the $40-49$ years age group (Table 1$)$. A total of $1117(75.5 \%)$ participants were female, 926 (62.6\%) were housewives, 667 (45.1\%) were illiterate, 1334 (90.1\%) were married, and 1391 (94\%) were of medium economic status. A total of $340(23 \%)$ participants were employed with 298 $(20.1 \%)$ being in the government office-based jobs.

Of 1480 study participants, 375 (25.3\%) were previously diagnosed with hypertension (Table 2). Among these, 330 $(88 \%)$ were regularly taking antihypertensive treatment, $22(5.9 \%)$ were taking the treatment irregularly, while 23 (6.1\%) were not taking their treatment. Two hundred and ninety-two (77.9\%) obtained their antihypertensive medication from private pharmacies and only 47 (12.5\%) from public hospitals without charge. Among the 1480 study participants, 809 (54.9\%) had hypertension, which included both the previously and newly diagnosed cases of hypertension, based on BP readings. Of these 809 hypertensive patients, 249 (30.8\%) were known cases of hypertension with uncontrolled BP, 126 (15.6\%) were known cases of hypertension with controlled BP, and 434 (53.6\%) did not know that they had hypertension but had a high BP reading on examination. Of the 434 newly diagnosed hypertension cases, 142 (32.5\%) had isolated systolic hypertension, $38(8.5 \%)$ had isolated diastolic hypertension, and the remaining 256 (59\%) had combined systolic and diastolic hypertension.

The participants with hypertension had a significantly higher mean age [54.3 (15.1) years] than those without 


\begin{tabular}{|c|c|c|}
\hline \multicolumn{3}{|c|}{$\begin{array}{l}\text { Table } 1 \text { Sociodemographic characteristics of the studied } \\
\text { sample }\end{array}$} \\
\hline Variable & Frequency & Percentage \\
\hline \multicolumn{3}{|l|}{ Age, $y r$} \\
\hline $20-29$ & 251 & 17.0 \\
\hline $30-39$ & 336 & 22.7 \\
\hline $40-49$ & 307 & 20.7 \\
\hline $50-59$ & 211 & 14.3 \\
\hline$>60$ & 375 & 25.3 \\
\hline \multicolumn{3}{|l|}{ Sex } \\
\hline Male & 363 & 24.5 \\
\hline Female & 1117 & $75 \cdot 5$ \\
\hline \multicolumn{3}{|l|}{ Occupation } \\
\hline Government, office-based & 298 & 20.1 \\
\hline Government, labour-based & 3 & 0.2 \\
\hline Private, office-based & 37 & 2.5 \\
\hline Private, labour-based & 2 & 0.1 \\
\hline Housewife & 926 & 62.6 \\
\hline Student & 35 & 2.4 \\
\hline None & 179 & 12.1 \\
\hline \multicolumn{3}{|l|}{ Education } \\
\hline Illiterate & 667 & 45.1 \\
\hline Primary & 339 & 22.9 \\
\hline Secondary & 170 & 11.5 \\
\hline Tertiary & 304 & 20.6 \\
\hline \multicolumn{3}{|l|}{ Marital status } \\
\hline Single & 142 & 9.6 \\
\hline Married & 1334 & 90.1 \\
\hline Divorced & 2 & 0.1 \\
\hline Widow & 2 & 0.1 \\
\hline \multicolumn{3}{|l|}{ Religion } \\
\hline Muslim & 1421 & 96.0 \\
\hline Christian & 59 & 4.0 \\
\hline \multicolumn{3}{|l|}{ Ethnicity } \\
\hline Kurd & 1388 & 93.8 \\
\hline Arab & 8 & 0.5 \\
\hline Turkman & 26 & 1.8 \\
\hline Chaldean/Assyrian & 58 & 3.9 \\
\hline \multicolumn{3}{|l|}{ Socioeconomic status } \\
\hline Poor & 55 & 3.7 \\
\hline Medium & 1391 & 94.0 \\
\hline Well & 34 & 2.3 \\
\hline
\end{tabular}

hypertension [36.8 $(11.8)$ years] $(P<0.001)$. There was a significant association between hypertension and increasing age, male sex, being married, low educational level, unemployment, poor economic situation, sedentary lifestyle, lack of regular physical exercise, and increasing body mass index (Table 3). A nonsignificant association was found with smoking, alcohol consumption, table salt intake, and positive family history of hypertension 3.

\begin{tabular}{|c|c|c|}
\hline Characteristic & Frequency & Percentage \\
\hline \multicolumn{3}{|l|}{ Previously diagnosed cases of hypertension } \\
\hline Yes & 375 & 25.3 \\
\hline No & 1105 & 74.7 \\
\hline \multicolumn{3}{|c|}{ Compliance with antihypertensive treatment $(n=375)$} \\
\hline Regularly take treatment & 330 & 88.0 \\
\hline Irregularly take treatment & 22 & 5.9 \\
\hline Do not take treatment & 23 & 6.1 \\
\hline \multicolumn{3}{|l|}{ Access to antihypertensive drugs $(\mathrm{n}=375)$} \\
\hline Public hospital & 47 & 12.5 \\
\hline Private pharmacy & 292 & 77.9 \\
\hline Missing data & 36 & 9.6 \\
\hline \multicolumn{3}{|l|}{ Prevalence of hypertension $(n=1480) a$} \\
\hline Hypertensive & 809 & 54.7 \\
\hline Not hypertensive & 671 & $45 \cdot 3$ \\
\hline \multicolumn{3}{|c|}{ Prevalence of stage 2 hypertension $(n=1480) b$} \\
\hline Hypertensive & 593 & 40.1 \\
\hline Not hypertensive & 887 & 59.9 \\
\hline \multicolumn{3}{|c|}{ Classification of hypertensive patients $(n=809)$} \\
\hline $\begin{array}{l}\text { Uncontrolled, known cases of } \\
\text { hypertension }\end{array}$ & 249 & 30.8 \\
\hline $\begin{array}{l}\text { Well controlled, known cases of } \\
\text { hypertension }\end{array}$ & 126 & 15.6 \\
\hline $\begin{array}{l}\text { Newly diagnosed cases of } \\
\text { hypertension based on examination }\end{array}$ & 434 & 53.6 \\
\hline \multicolumn{3}{|c|}{ Type of hypertension among newly diagnosed cases $(n=434)$} \\
\hline Systolic & 142 & 32.5 \\
\hline Diastolic & 38 & 8.5 \\
\hline Combined systolic and diastolic & 256 & 59.0 \\
\hline
\end{tabular}

${ }^{a}$ Using 130/80 mm Hg cutoff according to the new guidelines.

${ }^{b}$ Using 140/90 mm Hg cutoff.

The multivariate analysis identified age $(\mathrm{OR}=1.1$, $95 \% \mathrm{CI}=1.08-1.11)$, male sex $(\mathrm{OR}=2.72,95 \% \mathrm{CI}=1.91-$ 3.87), unemployment $(\mathrm{OR}=1.85,95 \% \mathrm{CI}=1.33-2.56)$, and obesity (OR $=2.20,95 \% \mathrm{CI}=1.51-3.21)$ as significant factors associated with hypertension (Table 4).

\section{Discussion}

Our study revealed that the prevalence of hypertension in our study population in Erbil City was 54.7\%. This prevalence is higher than that reported in a study in Nasiriyah City, Iraq in 2014 (26.5\%) (11) and that reported across Iraq in 2006 (40.4\%) (15) and by the WHO in $2013(40 \%)(13)$. Studies conducted in neighbouring countries have also shown a high prevalence of hypertension ranging from $32.3 \%$ in Jordan to $44 \%$ in Turkey (16-18). However, a lower prevalence of $26.1 \%$ was reported in Saudi Arabia (19). The high prevalence in our study was partially attributed to using a cutoff of $130 / 80 \mathrm{mmHg}$ according to the new guidelines (14), compared with a cutoff of $140 / 90 \mathrm{mmHg}$ in other studies. However, even the prevalence of stage 2 
Table 3 Association between hypertension prevalence and other variables

\begin{tabular}{|c|c|c|c|c|}
\hline \multirow[t]{2}{*}{ Variables } & \multicolumn{3}{|c|}{ Hypertension } & \multirow[t]{2}{*}{$\boldsymbol{P}$} \\
\hline & $\begin{array}{c}\text { Yes } \\
\text { No. (\%) }\end{array}$ & $\begin{array}{c}\text { No } \\
\text { No. }(\%)\end{array}$ & $\begin{array}{c}\text { Total } \\
\text { No. }(\%)\end{array}$ & \\
\hline \multicolumn{5}{|l|}{ Age groups ,yr } \\
\hline $20-29$ & $44(17.5)$ & $207(82.5)$ & $251(100)$ & \multirow{5}{*}{$<0.001$} \\
\hline $30-39$ & $96(28.6)$ & $240(71.4)$ & $336(100)$ & \\
\hline $40-49$ & $172(56.0)$ & $135(44.0)$ & $307(100)$ & \\
\hline $50-59$ & $164(77.7)$ & $47(22.3)$ & $211(100)$ & \\
\hline$>60$ & $333(88.8)$ & $42(11.2)$ & $375(100)$ & \\
\hline \multicolumn{5}{|l|}{ Sex } \\
\hline Male & $230(63.4)$ & $133(36.6)$ & $363(100)$ & \multirow{2}{*}{$<0.001$} \\
\hline Female & $579(51.8)$ & $538(48.2)$ & 1117 (100) & \\
\hline \multicolumn{5}{|l|}{ Marital status } \\
\hline Single & $42(29.6)$ & $100(70.4)$ & $142(100)$ & \multirow{2}{*}{$<0.001$} \\
\hline Ever married & $767(57.3)$ & $571(42.7)$ & $1338(100)$ & \\
\hline \multicolumn{5}{|l|}{ Education level } \\
\hline Illiterate & $460(69.0)$ & $207(31.0)$ & $667(100)$ & \multirow{4}{*}{$<0.001$} \\
\hline Primary & $153(45.1)$ & $186(54.9)$ & $339(100)$ & \\
\hline Secondary & $54(31.8)$ & $116(68.2)$ & $170(100)$ & \\
\hline Tertiary & $142(46.7)$ & $162(53.3)$ & 304 (100) & \\
\hline \multicolumn{5}{|l|}{ Employment } \\
\hline Employed & $151(44.4)$ & $189(55.6)$ & 340 (100) & \multirow{2}{*}{$<0.001$} \\
\hline Unemployed & $658(57.7)$ & $482(42.3)$ & $1140(100)$ & \\
\hline \multicolumn{5}{|l|}{ Economic status } \\
\hline Poor & $37(67.3)$ & $18(32.7)$ & $55(100)$ & \multirow{3}{*}{0.049} \\
\hline Medium & $758(54.5)$ & $633(45.5)$ & $1391(100)$ & \\
\hline Well & $14(41.2)$ & $20(58.8)$ & $34(100)$ & \\
\hline \multicolumn{5}{|l|}{ Smoking } \\
\hline No & $743(54 \cdot 3)$ & $626(45.7)$ & $1369(100)$ & \multirow{2}{*}{0.291} \\
\hline Yes & $66(59.5)$ & $45(40.5)$ & 111 (100) & \\
\hline \multicolumn{5}{|c|}{ Alcohol consumption } \\
\hline No & $797(54.9)$ & $654(45.1)$ & $1451(100)$ & \multirow{2}{*}{0.147} \\
\hline Yes & $12(41.4)$ & $17(58.6)$ & $29(100)$ & \\
\hline \multicolumn{5}{|l|}{ Table salt intake } \\
\hline No & $588(54.4)$ & $661(45.6)$ & $1449(100)$ & \multirow{2}{*}{0.139} \\
\hline Yes & $21(67.7 .2)$ & $10(32.3)$ & $31(100)$ & \\
\hline \multicolumn{5}{|l|}{ Lifestyle } \\
\hline Sedentary & $81(78.6)$ & $22(21.4)$ & $103(100)$ & \multirow{2}{*}{$<0.001$} \\
\hline Active & $728(52.9)$ & $649(47.1)$ & $1377(100)$ & \\
\hline Physical exercise & & & & \\
\hline No & $772(55.3)$ & $624(44.7)$ & $1396(100)$ & \\
\hline Yes & $37(44.0)$ & $47(56.0)$ & $84(100)$ & 0.044 \\
\hline Body mass index & & & & \\
\hline Normal weight & $108(37.1)$ & $183(62.9)$ & $291(100)$ & \\
\hline Overweight & $255(51.3)$ & $242(48.7)$ & 497 (100) & $<0.001$ \\
\hline Obesity & $444(64.8)$ & $241(35.2)$ & $685(100)$ & \\
\hline Family history of $h$ & pertension & & & \\
\hline No & $420(53.9)$ & $359(46.1)$ & 779 (100) & \\
\hline Yes & $389(55.5)$ & $312(44.5)$ & $701(100)$ & 0.543 \\
\hline
\end{tabular}

hypertension, which is based on a 140/90 $\mathrm{mmHg}$ cutoff, was still considerably high (40.1\%) in our study.

The prevalence of hypertension is always underestimated, especially in low- and middle-income countries (20), and the detection of high BP is made through routine examination or after the development of complications (21). Our study showed that $53.6 \%$ of the cases of hypertension were previously undetected, which comprised $29.3 \%$ of the study population. This percentage is higher compared to the $7.4 \%$ reported in the Nasiriyah study (11).

The present study showed a significant association between the prevalence of hypertension and sex $(63.4 \%$ for men and $51.8 \%$ for women). However, other studies from Nasiriyah (11), Turkey (18) and the Islamic Republic of Iran (22) showed a higher prevalence of hypertension among women compared to men. In general, some risk factors for developing hypertension such as increased body weight and sedentary lifestyle might be more common in women (23).

The significant association between hypertension and increasing age might be attributed to the increased arterial stiffness in older people. An epidemiological study conducted in 2004 showed that the prevalence of hypertension was increased more than 2-fold in the aged compared to younger population (24). Our results in this regard are also consistent with those of other studies from Nasiriyah City (11) and Central India (25). According to the Seventh Report of the Joint National Committee on Prevention, Detection, Evaluation, and Treatment of High Blood Pressure in 2003, more than two thirds of the population aged $>65$ years experienced hypertension (26).

We found a significant association between hypertension and marital status, with a prevalence of $57.3 \%$ among ever-married people compared to only $29.6 \%$ among the unmarried population. Married people are usually older than unmarried people, and this might explain the difference in prevalence of hypertension among these 2 groups. These results are also consistent with the studies from Nasiriyah City (11) and Central India (25). However, research has shown that married women have a lower risk of developing hypertension where marital happiness or satisfaction might play a role in attaining better health. However, experiencing change in marital status is likely to lead to some adverse effects, including hypertension (27).

The prevalence of hypertension was inversely related to the educational level in the present study. A significant association was found between hypertension and low educational level; $69 \%$ among the illiterate population, compared to $45.1 \%$ and $31.8 \%$ among participants with primary and secondary levels of education, respectively. These results are consistent with some other studies from Iraq and elsewhere $(11,28)$. Such an association could be primarily attributed to the low level of awareness among poorly educated people following a healthy lifestyle.

The prevalence of hypertension was significantly higher in unemployed people and those with lower 


\begin{tabular}{|c|c|c|c|c|c|c|}
\hline \multirow[t]{2}{*}{ Variable } & \multirow[t]{2}{*}{ B } & \multirow[t]{2}{*}{ SE } & \multirow[t]{2}{*}{ OR } & \multicolumn{2}{|c|}{$95 \% \mathrm{CI}$} & \multirow[t]{2}{*}{$\boldsymbol{P}$} \\
\hline & & & & Lower & Upper & \\
\hline Age & 0.090 & 0.006 & 1.09 & 1.08 & 1.11 & $<0.001$ \\
\hline Female & & & Ref & & & \\
\hline Male & 1.000 & 0.181 & 2.72 & 1.91 & 3.87 & $<0.001$ \\
\hline Single & & & Ref & & & \\
\hline Ever married & -0.463 & 0.248 & 0.63 & 0.39 & 1.02 & 0.062 \\
\hline Employed & & & Ref & & & \\
\hline Unemployed & 0.613 & 0.168 & 1.85 & 1.33 & 2.56 & $<0.001$ \\
\hline Well socioeconomic status & & & Ref & & & \\
\hline Medium socioeconomic status & 0.335 & 0.431 & 1.40 & 0.60 & 3.25 & 0.437 \\
\hline Poor socioeconomic status & 0.918 & 0.546 & 2.51 & 0.86 & $7 \cdot 31$ & 0.093 \\
\hline Regular exercise & & & Ref & & & \\
\hline No exercise & -0.003 & 0.284 & 1.0 & 0.57 & 1.74 & 0.992 \\
\hline Mild/moderate lifestyle & & & Ref & & & \\
\hline Sedentary lifestyle & -0.135 & 0.323 & 0.87 & 0.46 & 1.64 & 0.676 \\
\hline Normal weight & & & Ref & & & \\
\hline Overweight & 0.325 & 0.193 & 1.38 & 0.95 & 2.02 & 0.093 \\
\hline Obesity & 0.789 & 0.192 & 2.20 & 1.51 & 3.21 & $<0.001$ \\
\hline
\end{tabular}

$C I=$ confidence interval $\mathrm{OR}=$ odds ratio; $S E=$ standard error.

socioeconomic status. A meta-analysis showed an increased risk of hypertension among people with the lowest socioeconomic status, particularly for the indicators of income, occupation and education. The risk was particularly most evident for women (29).

Our study revealed a significant association between hypertension and increasing body mass index, with a prevalence of $64.8 \%$ among obese people compared to $51.3 \%$ and $37.1 \%$ among overweight and normal weight people, respectively. Our results were consistent with a study conducted in Central India (25). This association supports the fact that increased body weight is a primary risk factor for hypertension. The dietary patterns in Kurdistan might play a role in obesity and hypertension. The Iraqi diet is rich and varied as it reflects a rich inheritance as well as complex influences from the culinary traditions of Turkey, the Islamic Republic of Iran and the Syrian Arab Republic. The food involves large consumption of meat, especially lamb and chicken. It is also increasingly dependent on carbohydrates, primarily bread and rice, as any meal is rarely served without rice. The Iraqi diet is also characterized by high consumption of vegetables and fruit and moderate amounts of eggs, yogurt and cheese. However, it also has reduced consumption of fish or seafood $(30,31)$. The region has witnessed an unprecedented increase in the consumption of fast food. Therefore, the dietary pattern is rapidly changing to a unhealthy diet, which might even increase obesity and its complications such as CVDs (32).

It is well known that hypertension runs in the family, but unlike other studies, this study showed an insignificant association between hypertension and positive family history. It is possible that the participants lacked knowledge about the actual health status of their family members. Moreover, the environmental and lifestyle factors might have had more effect on developing hypertension than family history had. Several studies from Iraq and other countries have revealed a significant association between hypertension and positive family history $(11,25,33)$.

Sedentary lifestyle and lack of regular physical exercise were also significantly associated with high prevalence of hypertension in our study. Being physically inactive also leads to increased body weight, which in turn leads to increased BP. Several other studies have shown that sedentary lifestyle and lack of physical exercise are important risk factors for developing hypertension $(25,34)$.

The present study had several limitations. First, the study sample consisted mainly of female participants. The household visits were conducted during daylight hours when most male members of the household might have been out. We could not make follow-up visits to the households to interview the absent male adults due to logistic difficulties, such as lack of adequate funding and time available. Visiting the households for the survey purpose in the evening hours was also not culturally preferable in this locality. Second, there was the potential effect of white coat and masked hypertension on real prevalence. This problem is related to the variability of a patient's BP measurement between the physician's office and the patient's home environment. To limit the effect of these factors, we measured BP in the homes of the participants on 2 occasions and only after administering the questionnaire in a friendly manner. Third, we did not 
include important risk factors for CVDs, such as lipid profile. We did not include data that required taking blood samples and laboratory investigations because of financial constraints and the possibility that participants would refuse to provide consent for invasive procedures.

\section{Conclusions}

In Erbil City there was a high prevalence of hypertension and undiagnosed hypertension. Compliance with treatment was high, but access to drugs was mainly from private pharmacies. Hypertension was significantly associated with increasing age, male sex, unemployment and obesity. The high prevalence of hypertension in Erbil City necessitates effective preventive and control measures, including comprehensive health education activities, screening programmes, encouraging optimal and healthy lifestyles, and facilitating access to free or subsidized antihypertensive treatment.

\section{Funding: None.}

Competing interests: None declared.

\section{Prévalence de l'hypertension et facteurs de risque associés parmi la population âgée du Kurdistan (Iraq) \\ Résumé}

Contexte : L'hypertension est un problème de santé publique majeur et l'un des principaux facteurs de risque de morbidité et de mortalité dues aux maladies cardio-vasculaires.

Objectifs : Déterminer la prévalence de l'hypertension dans une population de personnes âgées à Erbil, Kurdistan (Iraq), et identifier les facteurs de risque associés.

Méthodes : Une enquête transversale en communauté basée sur des visites dans les ménages a été menée entre avril et juin 2017. Elle incluait 1480 adultes sélectionnés selon une méthode d'échantillonnage à plusieurs degrés. Nous avons utilisé un questionnaire conçu spécialement pour recueillir des données sociodémographiques et cliniques auprès des participants, grâce à des entretiens directs et à la mesure de leur tension artérielle.

Résultats : Sur les 1480 participants, 809 (54,7\%) avaient une hypertension artérielle. Sur ces 809 patients hypertendus, $375(46,4 \%)$ avaient une hypertension connue et 434 (53,6 \%) ont été diagnostiqués au cours de l'enquête. L'analyse multivariée a identifié l'âge [odds ratio $(\mathrm{OR})=1,1$, intervalle de confiance à $95 \%$ (IC) =1,08-1,11], le sexe masculin (OR = 2,72, IC à $95 \%$ = 1,91-3,87), le chômage (OR = 1,85, IC à $95 \%=1,33-2,56)$ et l'obésité $(\mathrm{OR}=2,20$, IC à 95\% = 1,51-3,21) comme facteurs significatifs associés à l'hypertension.

Conclusions : La prévalence de l'hypertension à Erbil est forte, avec une prévalence élevée d'hypertension non diagnostiquée. L'observance thérapeutique était bonne, mais l'accès aux médicaments dépendait principalement des pharmacies privées. Cette forte prévalence de l'hypertension à Erbil nécessite des mesures de prévention et de lutte efficaces, notamment des programmes complets d'éducation sanitaire et de dépistage.

$$
\begin{aligned}
& \text { ارتفاع ضغط الدم والعو امل المرتبطة به في صفوف البالغين الأكبر سناً في كردستان، العراق } \\
& \text { مريو ان ساكا، شيرزاد شابو، نزار شابيلة } \\
& \text { الخالاصة } \\
& \text { الخلفية: يُعتبر ارتفاع ضغط الدم من المشكلات الصحية العامة وأحد عو امل الخطر الرئيسية التي تؤدي إلى الوفاة والمر اضة بسبب أمراض القلب } \\
& \text { والأوعية الدموية. } \\
& \text { الأهداف: هدفت الدراسة إلى تحديد مدى انتشار ارتفاع ضغط الدم بين السكان من البالغين الأكبر سناً في أربيل، كردستان، العراق، وتحديد عو امل } \\
& \text { الخطر المرتبطة به. }
\end{aligned}
$$

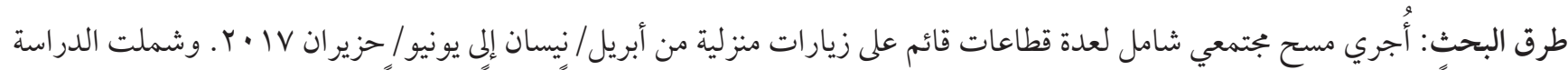

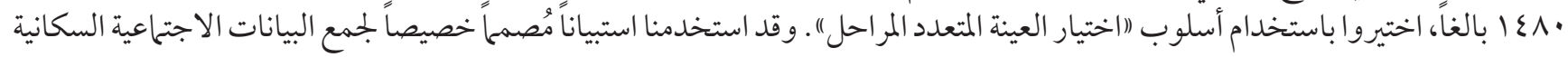

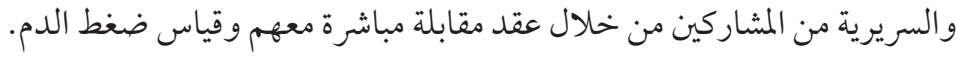

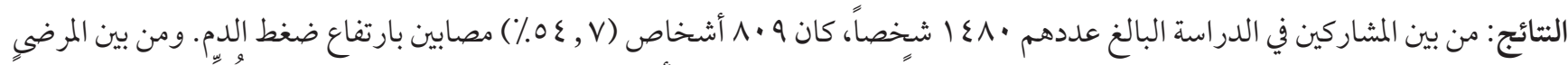

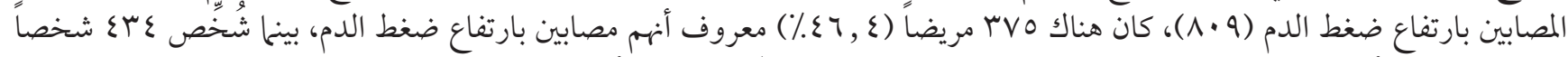

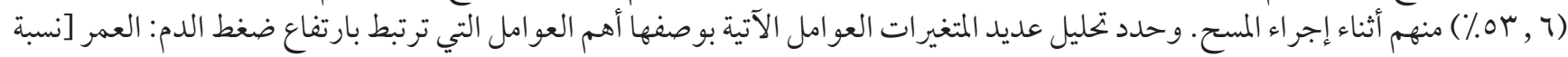

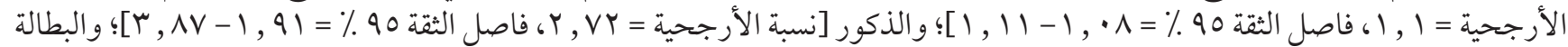

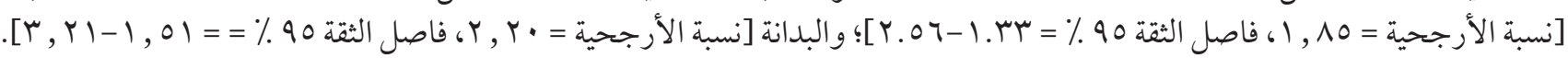




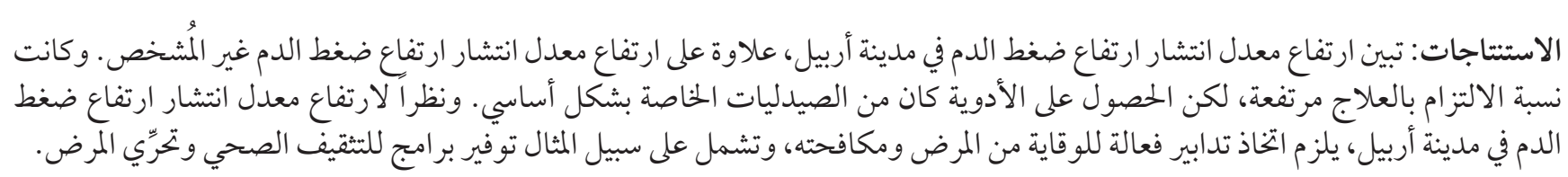

\section{References}

1. James PA, Oparil S, Carter BL, Cushman WC, Dennison-Himmelfarb C, Handler J, et al. 2014 evidence-based guideline for the management of high blood pressure in adults: report from the panel members appointed to the Eighth Joint National Committee (JNC 8). JAMA. 2014 Feb 5;311(5):507-20. http://dx.doi.org/10.1001/jama.2013.284427 PMID:24352797

2. Kearney PM, Whelton M, Reynolds K, Muntner P, Whelton PK, He J. Global burden of hypertension: analysis of worldwide data. Lancet. 2005 Jan 15-25;365(9455):217-23. http://dx.doi.org/10.1016/So140-6736(05)17741-1 PMID:15652604

3. Perkovic V, Huxley R, Wu Y, Prabhakaran D, MacMahon S. The burden of blood pressure-related disease: A neglected priority for global health. Hypertension. 2007 Dec;50(6):991-7. http://dx.doi.org/10.1161/HYPERTENSIONAHA.107.095497 PMID:17954719

4. The world health report 2002 - reducing risks, promoting healthy life. Geneva: World Health Organization; 2002 (https://www. who.int/whr/2002/en/, accessed 15 August 2019).

5. Park K. Epidemiology of chronic non-communicable diseases and conditions. In: Park's textbook of preventive and social medicine. 18th edition. Jabalpur, India: M/s Banarasidas Bhanot Publishers; 2005:285-328.

6. A global brief on hypertension: silent killer, global public health crisis: World Health Day 2013. Geneva: World Health Organization; 2013 (https://apps.who.int/iris/handle/10665/79059, accessed 15 August 2019).

7. Habibzadeh F. Hypertension in the Middle East. Lancet. 2012;380:1.

8. Lawes CM, Hoorn SV, Rodgers A. Global burden of blood-pressure-related disease, 2001. Lancet. 2008 May 3;371(9623):1513-18. http://dx.doi.org/10.1016/So140-6736(08)60655-8 PMID:18456100

9. Ministry of Health, Directorate of Public Health and Primary Health Care and Ministry of Planning and Development in collaboration with World Health Organization. Chronic non communicable diseases risk factors survey in Iraq 2006. A STEP wise approach. (www.who.int/chp/steps/IraqSTEPSReport2006.pdf ?ua=1, accessed 15 August 2019).

10. World Health Statistics 2012. Part II highlighted topics. Geneva: World Health Organization; 2012 (https://www.who.int/gho/ publications/world_health_statistics/EN_WHS2012_Part2.pdf?ua=1, accessed 15 August 2019).

11. Al-Ghuzi AAS, Al-Asadi JN. Prevalence and socio-demographic determinants of hypertension in Thi-Qar governorate: a household survey. Am J Adv Drug Deliv. 2014;2(6):802-15.

12. Bello M. Nigerians wake up to high blood pressure. Bull World Health Organ. 2013 Apr 1;91(4):242-3. http://dx.doi.org/10.2471/ BLT.13.020413 PMID:23599546

13. Iraq celebrates World Health Day under the theme of hypertension [website]. Cairo: World Health Organization Regional Office for the Eastern Mediterranean (http://www.emro.who.int/irq/iraq-events/world-health-day.html, accessed 15 August 2019).

14. Whelton PK, Carey RM, Aronow WS, Casey Jr DE, Collins KJ, Dennison Himmelfarb C, et al. 2017 ACC/AHA/AAPA/ABC/ACPM/ AGS/APhA/ASH/ASPC/NMA/PCNA guideline for the prevention, detection, evaluation, and management of high blood pressure in adults. Hypertension. 2018 Jun;71(6):1269-1324. http://dx.doi.org/10.1161/HYP.0000000000000066 PMID:29133354

15. Fisher ND, Williams GH. Hypertensive vascular disease. In: Kasper DL, Braunwald E, Hauser S, Longo D, Jameson JL, Fauci AS, editors. Harrison's principles of internal medicine, 16th edition. New York: McGraw-Hill; 2005: 1463-81.

16. Jaddou HY, Batieha AM, Khader YS, Kanaan AH, EL-Khateeb MS, Ajlouni KM. Hypertension prevalence, awareness, treatment and control, and associated factors: Results from a national survey, Jordan. Int J Hypertens. 2011;Article ID 828797. Http://dx.doi. org/10.4061/2011/828797.

17. Maziak W, Rastam S, Mzayek F, Ward K, Essenberg T, Kiel U. Cardiovascular health among adults in Syria: a model from developing countries: Ann Epidemiol. 2007 Sep; 17(9):713-20. http://dx.doi.org/10.1016/j.annepidem.2007.03.016 PMID:17553700

18. Erem C, Hacihasanoglu A, Kocak M, Deger O, Topbas M. Prevalence of prehypertension and hypertension and associated risk factors among Turkish adults: Trabzon Hypertension Study. J Public Health (Oxf). 2009 Mar;31(1):47-58. http://dx.doi. org/10.1093/pubmed/fdno78 PMID:18829520

19. Al-Nozha MM, Abdullah M, Arafah MR, Khalil MZ, Khan NB, ALMazrou YY, et al. Hypertension in Saudi Arabia. Saudi Medical Journal. 2007 Jan;28(1):77-84. PMID:17206295

20. Addo J, Smeeth L, Leon DA. Hypertension in Sub-Saharan Africa: a systematic review. Hypertension. 2007 Dec;50(6):1012-18. http://dx.doi.org/10.1161/HYPERTENSIONAHA.107.093336 PMID:17954720

21. Redondo-Sendino A, Guallar-Castillón P, Banegas JR, Rodríguez-Artalejo F. Gender differences in the utilization of health-care services among the older adult population of Spain. BMC Public Health. 2006 Jun 16;6:155. http://dx.doi.org/10.1186/1471-2458-6155 PMID:16780576

22. Janghorbani M, Amini M, Gouya MM, Delavari A, Alikhani S, Mahdavi A. Nationwide survey of prevalence and risk factors of prehypertension and hypertension in Iranian adults. Journal of Hypertension. 2008 Mar;26(3):419-26. http://dx.doi.org/10.1097/ HJH.obo13e3282f2d34d PMID:18300850 
23. Agrawal P, Gupta K, Mishra V, Agrawal S. Effects of sedentary lifestyle and dietary habits on body mass index change among adult women in India: findings from a follow-up study. Ecol Food Nutr. 2013 Sep;52(5):387-406. http://dx.doi.org/10.1080/036702 44.2012.719346 PMID:23927045

24. Ong KL, Cheung BM, Man YB, Lau CP, Lam KS. Prevalence, awareness, treatment, and control of hypertension among United States adults 1999-2004. Hypertension. 2007 Jan;49(1):69-75. http://dx.doi.org/10.1161/01.HYP.0000252676.46043.18 PMID:17159087

25. Bhadoria AS, Kasar PK, Toppo NA, Bhadoria P, Pradhan S, Kabirpanthi V. Prevalence of hypertension and associated cardiovascular risk factors in Central India. J Family Community Med. 2014 Jan;21(1):29-38. http://dx.doi.org/10.4103/2230-8229.128775 PMID:24695988

26. Chobanian AV, Bakris GL, Black HR, Cushman WC, Green LA, Izzo JL, et al. Seventh report of the Joint National Committee on Prevention, Detection, Evaluation, and Treatment of High Blood Pressure. Hypertension. 2003 Dec;42(6):1206-52. http://dx.doi. org/10.1161/01.HYP.0000107251.49515.c2 PMID:14656957

27. Wang H. Effects of marital status and transition on hypertension in Chinese women: a longitudinal study. Paper presented at the 2005 annual meeting of the Population Association of America (https://pdfs.semanticscholar.org/f8oc/264c8201c34b3e15cfc72137bdaba82585eb.pdf, accessed 15 August 2019).

28. Ekezie J, Adebisi SS, Danborno B. The effect of marital status and self-reported physical exercise on the adiposity and blood pressure of the Igbos of Nigeria. Internet J Med Update. 2009 Jan;4(1):7-14. https://www.akspublication.com/Papero2_Jan2009_.pdf?

29. Leng B, Jin Y, Li G, Chen L, Jin N. Socioeconomic status and hypertension: a meta-analysis. J Hypertens. 2015 Feb;33(2):221-9. http://dx.doi.org/10.1097/HJH.0000000000000428 PMID:25479029

30. Salloum H. Foods of Iraq: enshrined with a long history. Things Asian. 2006. (http://thingsasian.com/story/foods-iraq-enshrinedlong-history, accessed 15 August 2019).

31. Salma KJ, Wafaa AA, Zainab A. A study of eating habits among female nursing students in the university of Babylon/Iraq. J Contemp Med Sci. 2016 Autumn;2(8):141-147. http://www.jocms.org/index.php/jcms/article/view/102

32. Keefe C. Baghdad burgers: fast food gaining popularity in Iraq. Grub Street. 2012. (http://www.grubstreet.com/2012/08/fast-foodblowing-up-in-iraq.html, accessed 15 August 2019).

33. Gupta R, Gupta VP. Hypertension epidemiology in India. Curr Sci. 2009 Aug 10;97(3):349-55. http://www.environmentportal.in/ files/Hypertension\%20epidemiology\%20in\%20India.pdf

34. Bonsa F, Gudina EK, Hajito KW. Prevalence of hypertension and associated factors in Bedele Town, Southwest Ethiopia. Ethiop J Health Sci. 2014 Jan;24(1):21-6 (PMID: 24591795 PMCID: PMC3929924 DOI: 10.4314/ejhs.v24i1.3). 